\title{
The Rise of Technocracy and the COVID-19 Pandemic in Taiwan: Courts, Human Rights, and the Protection of Vulnerable Populations
}

\author{
Tsung-Ling Lee (i) \\ Graduate Institute of Health \& Biotechnology Law, Taipei Medical University, Taipei, Taiwan \\ Corresponding author: t1265@georgetown.edu
}

(Received 01 May 2021; accepted 25 June 2021)

\begin{abstract}
Driven by the need to address the immediate public health threats of the COVID-19 pandemic, this has seen a rise of the technocratic mode of governance around the world. A technocratic approach is evidencebased and relies upon the guidance of experts to respond to the public health crisis. The rise of technocracy reflects a utilitarian calculus that seeks to preserve the greater good. Taiwan's pandemic response exemplifies the strengths and weaknesses of this type of governance. Based on an analysis of the relevant case law of the Taiwan Constitutional Court, legislation, and political developments this Article takes a legal-historical look and traces the current technocratic approach-defined for this Article as an experts-driven and procedural-driven process - which is a hallmark of Taiwan's pandemic response. Examining Taiwan's pandemic response through a human rights lens sheds light on a more complex relationship between the collective right to health and life, and the individual rights to health, work, privacy, and liberty during the pandemic.
\end{abstract}

Keywords: COVID-19 pandemic; Technocracy; Human rights; Constitutional court; Vulnerable populations

\section{A. Introduction}

By June 25, 2021, the COVID-19 pandemic had spread to 214 countries and territories, affecting 18 billion individuals and resulting in 3.9 million deaths. ${ }^{1}$ The sheer scale and magnitude of SARSCoV-2 have made the virus far more transmissible than MERS-CoV or SARS-CoV, penetrating national borders with ease. ${ }^{2}$ Driven by the need to protect public health during the pandemic, technocracies have become synonymous with the pandemic in parts of the world. ${ }^{3}$ A technocratic

The author acknowledges, with gratitude, for the enlightening feedbacks from Patrycja Dąbrowska-Kłosińska, Thérèse Murphy, Pedro A. Villarreal and participants at the Protection of Human Rights in Infectious Disease Control: Lessons for Global Health Governance from a Comparison of National Judicial Practice Symposium. The author would also like to thank Chien-Liang Lee, Wen-Yu Chia, Chih-Ming Liang and the anonymous reviewer for insightful comments and suggestions on the previous draft. Many thanks to the editors at the Washington and Lee University School of Law for excellent editorial assistance. All errors are my own.

Tsung-Ling Lee is an assistant Professor at the Graduate Institute of Health \& Biotechnology Law, Taipei Medical University, Taipei, Taiwan.

${ }^{1}$ COVID-19 CORONAVIRUS PANDEMIC, WORLDOMETER (Jun. 25, 2021), https://www.worldometers.info/coronavirus/.

${ }^{2}$ Eskild Petersen, Marion Koopmans, Unyeong Go, Davidson H. Hamer, Nicola Petrosillo, Francesco Castelli, Merete Storgaard, Sulien Al Khalili, \& Lone Simonsen, Comparing SARS-CoV-2 with SARS-CoV and Influenza Pandemics, LANCET (Jul. 3, 2020), https://www.thelancet.com/journals/laninf/article/PIIS1473-3099(20)30484-9/fulltext.

${ }^{3}$ Richard Horton, Offline: The Coming Technocracy, 396 LANCET 10266, 1896 (2020). 
approach is evidence-based and relies upon the guidance of experts to respond to the public health crisis. The rise of technocracy reflects a utilitarian calculus that seeks to preserve the greater good. In many ways, the pandemic and a technocratic government make natural bedfellows. Yet, as states play a quintessential and proactive role in maximizing their available resources-financial, natural, human, and technological resources - to protect their populations against the pandemic, tension exists between public health and individual human rights.

Taiwan, a self-governing island nation with a population of 23.5 million, was initially predicted to be one of the worst-hit countries. However, the country has managed the pandemic surprisingly well during the first year. Taiwan's relative success in containing the pandemic is attributed to various factors; ${ }^{4}$ one major factor is its centralized response. Yet in late April, the following year, a cascade of missteps resulted in the worst outbreak the country had seen since the start of the pandemic. While the outbreak remains relatively small by the international standard—at the peak of the outbreak Taiwan recorded around 500 cases per day-Taiwan's pandemic response is infused with utilitarian overtone, characterized as a technocratic response to the pandemic. As of June 25, Taiwan has 14,465 cases and 610 deaths. $^{5}$

Based on an analysis of the relevant case law of the Taiwan Constitutional Court, legislation, and political developments this Article takes a legal-historical look and traces the current technocratic approach - defined for this Article as an experts-driven and procedural-driven processwhich is a hallmark of Taiwan's pandemic response. Examining Taiwan's pandemic response through a human rights lens sheds light on a more complex relationship between the collective right to health and life, and the individual rights to health, work, privacy, and liberty during the pandemic. Like elsewhere, the government is granted exceptional power during the pandemic as it plays an essential role in mitigating the public health crisis. International human rights law also recognizes the necessity for states to limit human rights in times of public health crisis to protect collective interests. This extraordinary power has seen the government acting proactively and responsively, which largely fulfilled the obligation to protect the right to life during the first sixteen months of the pandemic.

A close examination of Taiwan's pandemic response reveals that there are clear instances where human rights and a technocratic approach are mutually reinforcing. Given that a technocratic approach concerns the protection of public health, the approach moves the public discourse away from an individualist framing of rights and carves out space for solidarity through institutionalizing processes that shape a shared identity. A technocratic approach is arguably better at promoting a positive vision of human rights, where governments play a proactive role in mitigating the pandemic. Accordingly, as the analysis shows, a technocratic approach places central importance upon preserving the right to life and health, which essentially maintains the normality of life during the first year of the pandemic. Thus, from a human rights perspective, a technocratic approach as a pandemic response is not necessarily a bad thing; it might be desirable insofar as protecting the right to life and health is concerned. For instance, as this Article shows, through the exceptional power granted to the Taiwanese government, the government was able to establish a national mask rationing scheme in Taiwan. The wide availability of masks thereby protects the right to life and health by significantly reducing community transmission.

However, a technocratic government is also a crisis government designed to address imminent public health challenges. As such, a technocratic government tends to perceive the population as monolithic. Moreover, as a technocratic approach prioritizes the right to life and health above

\footnotetext{
${ }^{4}$ See, e.g., Jennifer Summers, Hao-Yuan Cheng, Hsien-Ho Lin, Lucy Telfar Barnard, Amanda Kvalsvig, Nick Wilson, \& Michael G. Baker, Potential Lessons from the Taiwan and New Zealand Health Responses to the COVID-19 Pandemic, 4 Lancet Reg'l Health: Western Pac. 100044 (2020); Tsung-Ling Lee, Legal Preparedness as Part of COVID-19 Response: The First 100 Days in Taiwan, BMj Global (May 2020).

${ }^{5}$ CECC Confirms 76 Indigenous COVID-19 Cases, TAIwan Centers for Disease Control (Jun. 25, 2021), https://www. cdc.gov.tw/En/Bulletin/Detail/E-ASDE_r5SRl_0Mk4wA5xw?typeid=158.
} 
other human rights, it is underpinned by a heavy utilitarian undertone. Viewing the pandemic through a utilitarian lens neglects the fact that the pandemic has a disparate impact on different population groups. This Article, therefore, demonstrates there remains a critical need to consider the population-level impacts of the pandemic on vulnerable populations. Accordingly, this Article argues that the technocratic response needs to be more fully anchored in human rights. Specifically, this Article highlights how international human rights law provides a useful lens to explore various forms of vulnerabilities exposed by structural inequality and demonstrates how the principles of human rights can guide a technocratic response during pandemics. As the pandemic is more than a public health crisis, a technocracy can neglect the fact that the pandemic is also a human crisis. Consequently, in the second year, when the first major local outbreak erupted in Taiwan, vulnerable groups-healthcare workers, essential workers, older persons, migrant workers, and women for instance-are also disproportionately impacted.

While the analysis is specific to Taiwan, this Article aims to extrapolate general lessons insofar as the language of human rights holds universality. Integrating a human rights perspective into a pandemic response can be challenging, particularly as collective and individual interests collide. While not all human rights are absolute during the pandemic, human rights principles-necessity, legality, proportionality-help clarify the scope and duration of public power during the pandemic. Further, as international human rights law is part of Taiwan's legal order, human rights norms help address the concern of an unwarranted, broad public authority under the guise of public health by giving clarity and specificity to the use of exceptional power. Likewise, ensuring COVID measures are subject to parliamentary and judicial oversights remains central in maintaining the moral and legal legitimacy of the technocracy during the pandemic.

Focusing on Taiwan as a case study, this Article first describes the Constitutional jurisprudence where the Constitutional Court upheld the constitutionality of a compulsory quarantine order during the 2003 SARS outbreak, shaping subsequent judicial practices and the legal landscape. Second, this Article provides an overview of the laws and governance structure of technocracy in Taiwan. Third, this Article asks if, and how, the technocracy stands in tension or conformity with a stauncher version of human rights-where states have a positive obligation to protect the right to life and health-in Taiwan. By reference to the International Covenant on Economic, Social, and Cultural Rights (ICESCR) ${ }^{6}$ and the International Covenant on Civil and Political Rights (IPPCR), ${ }^{7}$ this Article presents a more complex, nuanced picture of the roles of government and the judiciary during the pandemic.

\section{B. Health and Human Rights in the Constitutional Jurisprudence: The SARS Experience}

\section{Human Rights and the Constitutional Court}

To understand the human rights implications arising from the current technocratic approach, I first turn to the 2003 SARS outbreak where controversies stemming from public health measures prompted the Constitutional Court to step-in and clarify the scope of constitutional rights in times of a public health crisis. In Taiwan, two intertwined factors underpinned the rise of a technocratic response during the COVID-19 pandemic: The devastation of the 2003 SARS outbreak and the affirmation of the Constitutional Court in limiting liberty during public health emergencies. These two elements laid the groundwork for a technocratic response in Taiwan-with a mixed result so far.

\footnotetext{
${ }^{6}$ International Covenant on Economic, Social and Cultural Rights (ICESCR), Dec. 16, 1966, 993 U.N.T.S. 3, https://www. refworld.org/docid/3ae6b36c0.html.

${ }^{7}$ International Covenant on Civil and Political Rights (IPPCR), Dec. 16, 1966, 999 U.N.T.S. 171, https://www.refworld.org/ docid/3ae6b3aa0.html.
} 
The Constitution Court, also known as the Council of Grand Justices, is responsible for interpreting the Constitution of Taiwan and is charged with unifying interpretations of the law. ${ }^{8}$ The Constitutional Court consists of fifteen justices ${ }^{9}$ where appointments consist of an eight-year term. Justices are drawn from six different professional backgrounds: (1) Supreme Court judges; (2) public prosecutors with outstanding performance; (3) practicing lawyers with distinguished legal careers as members of the Legislative Yuan; (4) distinguished professors; (5) judges from international courts or other public law specialists; and (6) individuals with distinguished legal and political careers. ${ }^{10}$

The Constitutional Court has jurisdiction over: (1) The constitutionality of laws and constitutional complaints; (2) disputes over constitutional organs; (3) impeachment of the President and the Vice President; (4) dissolution of unconstitutional political parties; (5) local self-government; and (6) uniform interpretation of statutes and regulations. ${ }^{11}$ When the Constitutional Court reviews a case, the Court examines the constitutionality of a law separate from the case that gave rise to the petition for an interpretation. The rulings are consecutively numbered and are available on the Judicial Tuan's website. ${ }^{12}$

The Taiwanese Constitution-with Taiwan known formally as the Republic of China-was enacted on December 25, 1946 and implemented on December 25, 1947. ${ }^{13}$ Between 19491987, many of the constitutional rights of the people were suspended because of the then-authoritarian regime. After 1987, the Bill of Rights Chapter in the Constitution facilitated Taiwan's democratization process and enhanced human rights protection; from 1991 to 2005, the Constitution underwent several amendments. The Constitution contains 175 articles that are spread across 14 chapters and enshrine the common aspiration to a fair and just society. ${ }^{14}$ Pertinent to the discussion is Chapter II, the Bill of Rights Chapter, which provides a list of fundamental rights ranging from civil to political, social, and economic rights. ${ }^{15}$ Article 22 provides all other freedoms and rights that are not detrimental to social order which are provided for under the Constitution. Article 23 is the limiting clause which provides that "all the freedoms and rights enumerated in the preceding articles shall not be restricted by law except when as may be necessary to prevent infringement upon the freedoms of other persons, to avert an imminent crisis, to maintain social order or to advance public welfare."16

The tension between the exercise of individual liberty and the protection of public health first came to light during the 2003 Severe Acute Respiratory Syndrome (SARS) outbreak, when the government ordered compulsory quarantine of over 1,000 healthcare workers, patients, and their families and caretakers-irrespective of whether they were confirmed as carrying the virus or not

\footnotetext{
${ }^{8}$ For an overview of the procedural and substantive requirements for petitions to the Constitutional Court, please see Margaret K. Lewis \& Jerome A. Cohen, How Taiwan's Constitutional Court Reined in Police Power: Lessons for the People's Republic of China, 37 Fordham InT'L L.J. 863, 871-72 (2014).

${ }^{9}$ Judicial Yuan Organization Act, art. 3, (JudiCIAL YUAN), rev'd Jun. 6, 2020, https://law.moj.gov.tw/ENG/LawClass/LawAll. aspx?pcode $=$ A0010051 (Taiwan).

${ }^{10} \mathrm{Id}$. at art. 4

${ }^{11}$ Constitutional Court Procedure Act (JUDICIAL YUAN), rev'd Jan. 4, 2019, https://law.moj.gov.tw/ENG/LawClass/LawAll. aspx?pcode $=\mathrm{A} 0030159$ (Taiwan).

${ }^{12}$ Interpretations, CONST. CT. INTERP., JUdICIAL YUAN, R.O.C. https://cons.judicial.gov.tw/jcc/zh-tw/jep03.

${ }^{13}$ Chang-fa Lo, The Approach of Introducing International Human Rights Treaties into the Interpretation of Constitutional Provisions in Taiwan, in Taiwan and InTernational Human Rights 275 (Jerome Cohen, William Alford \& Chang-fa Lo eds., 2019).

${ }^{14}$ For an overview on the Constitution, please see Lewis \& Cohen, supra, note 8.

${ }^{15}$ For instance, equal protection and personal freedom are guaranteed. Equal protection is provided by Article 7, individual liberty is provided by Article 8, freedom of speech is provided by Article 11, the right to privacy is guaranteed by Article 12, freedom of assembly is protected by Article 14, the right to work is provided by Article 15, the right to justice is protected by Article 16, the right to election is protected by Article 17, the right to holding public offices is provided in Article 18, and the right to education is guaranteed in Article 21.

${ }^{16}$ MinguO XIANFA art. 23 (1947) (Taiwan), https://law.moj.gov.tw/ENG/LawClass/LawAll.aspx?pcode=A0000001.
} 
- after a suspected cluster of infection emerged in a municipal hospital, Heping Hospital, located in the city of Taipei. ${ }^{17}$ Off-duty medical doctors and nurses were recalled back to the hospital to quarantine with individuals who had confirmed diagnoses for two weeks. Public panic ensued after the Taipei City government made the decision abruptly. The media's portrayal of the situation further fueled collective anxieties, stigmatizing medical staff at the municipal hospital. Refusals to obey the city government's order were publicly shunned. The decision to quarantine healthy individuals along with those who had confirmed infections infused panic, helplessness, and desperation inside the hospital. ${ }^{18}$ Quarantined individuals hung banners begging for help from the windows of the hospital that was under lock down. The government's failure to provide protective equipment or to issue any clear guidelines for quarantine, fueled desperation within the hospital. ${ }^{19}$ A surgery specialist, Dr. Ching-kai Chou, who refused to return to the hospital-WHO recommended home quarantine would suffice as a public health measure-became a media sensation. Dr. Chou's open defiance was portrayed as disobedience, and he was dubbed as the doctor "who ran away" from his social responsibility. Although Dr. Chou finally succumbed to social pressure and returned to the hospital for quarantine, the city government fined Dr. Chou for insubordination, suspended his medical license for three months, and dismissed him from the hospital. ${ }^{20}$ This was despite the fact that the erroneous quarantine policy resulted in cross-infection of fifty-seven medical workers and seven deaths, and among patients, ninety-seven were infected, resulting in twenty-four deaths. ${ }^{21}$ Strikingly, during the impeachment trial conducted after the incident and the subsequent court cases concerning hospital mismanagement and potential misconduct of the city government, no one was found guilty. ${ }^{22}$

Dr. Chou then spent seven years appealing his case ${ }^{23}$ and when the Constitutional Court finally took the case, the interpretation had an unquestionable tone of utilitarianism-which implicitly affirmed that during an infectious disease outbreak, individual liberty must yield to public interest and that the state can impose a quarantine if procedural requirements are met. ${ }^{24}$ In Judicial Yuan Interpretation No. 690, the Constitutional Court affirms the necessity of compulsory quarantine as a public health measure to prevent the spread of infectious diseases. ${ }^{25}$ While the Constitutional

\footnotetext{
${ }^{17}$ Han Cheung, Taiwan in Time: Remembering the SARS lockdown, TAIPEI TIMES (Apr. 19, 2020), https://www.taipeitimes. com/News/feat/archives/2020/04/19/2003734881.

${ }^{18}$ Melody Chen, A View From Inside: Life Under Quarantine, TAIPEI TimEs (May 6, 2003), https://www.taipeitimes.com/ News/taiwan/archives/2003/05/06/0000204853. See, e.g., Chang Tze-wu, The SARS Doctors: How Three Doctors Survived Taiwan's Worst Quarantine, TAIWAN GAZETTE (Jun. 28, 2020), https://www.taiwangazette.org/news/2020/6/28/the-sarsdoctors-how-three-doctors-survived-taiwans-worst-quarantine (reporting that one individual committed suicide during the hospital quarantine).

${ }^{19}$ Investigation Report 093, Financial Adjustment 0031, CONTROL YuAN RePorT (Feb. 07, 2018), https://www.cy.gov.tw/ CyBsBoxContent.aspx? $\mathrm{s}=66$ (Taiwan).

${ }^{20}$ ("A public servant is subject to punitive dismissal when he or she ... violates major government orders, or seriously harms the credibility of the government, with definite evidence.”). See also Physicians Act, art. 25(I)(4) (“A physician guilty of any of the following conditions shall be disciplined by the Medical Association or the competent authority: ... violating medical ethics in his or her professional practice.").

${ }^{21}$ After the SARS Incident on 4/24, the 17th Anniversary of the Closure of Heping Hospital, PTS TAIWAN (Apr. 24, 2020), https://news.pts.org.tw/article/476077.

${ }^{22}$ In addition to the impeachment trial, an individual at the senior level of Heping Hospital was charged with mismanaged of the hospital outbreak and was found not guilty. See Control YUAN RePORT, supra note 19.

${ }^{23} \mathrm{Dr}$. Chou has also volunteered to return to the frontline during the Covid pandemic from retirement. In an effort to restore his reputation, Dr. Chou has appealed to the National Human Rights Commission this year, which is housed under the Control Yuan (Ombudsman) responsible for investigating human rights complaints. As the National Human Rights Commission is a newly established public institution, it remains to be seen how the Commission will deal with Dr. Chou's case.

${ }^{24}$ Specifically, the Constitutional Court examined the compulsory quarantine order through the principles of legal clarity and proportionality, and whether the order is in violation of Article 8 of the Constitution concerning individual liberty.

${ }^{25}$ Interpretation No. 690, CONST. CT. INTERP., JUDICIAL YUAN, R.O.C., para. 6, https://cons.judicial.gov.tw/jcc/en-us/jep03/ show? expno=690https://cons.judicial.gov.tw/jcc/en-us/jep03/show?expno=708 (Taiwan).
} 
Court is reluctant to second-guess public health decisions made during public health emergencies, it recognizes that the deprivation of liberty during public health emergencies is different from a criminal case and that the public health measure would be deemed constitutional if: A legitimate public health goal exists, the restriction of liberty is made based on available scientific evidence, and the measure is appropriate and proportionate to achieve that goal. As such, the Constitutional Court recognized that the affected individuals should be afforded procedural protections during an infectious disease outbreak if subjected to restrictions due to public health. The Constitutional Court instructed the legislature to amend the Communicable Diseases Control Act (CDC Act) in ensuring adequate procedural protection would be afforded to those affected individuals, including setting a clear stipulation, a reasonable period for those who are subjected to mandatory quarantines, and providing monetary compensation to affected individuals and their families. ${ }^{26}$

The Constitutional Court distinguished between the deprivation of liberty during a public health crisis from that of a criminal case, where the latter would be entitled to judicial review by which courts must make a determination within twenty-four hours about the legality of the arrest. Yet, the Constitutional Court was reluctant to recognize that such a right exists in public health emergencies. Instead, the Court affirmed the police power of the administrative branch because of their perceived medical expertise and the urgency that underpins public health emergencies. Although the Court did not affirm that the affected individual would be entitled to judicial review during a public health emergency, human rights advocates argue that the opposite would be contrary to obligations stipulated in international human rights law. Consequently, when the Habeas Corpus Act was adopted in 2014, the Act established a habeas corpus review mechanism which allows affected individuals to petition for a writ of habeas corpus when subjected to a quarantine order. Further, in Judicial Yuan Interpretation no. $708,{ }^{27}$ the Constitutional Court also recognizes that the habeas corpus protection extends to foreigner nationals, thus keeping in line with the Constitution on equal protection.

In short, the Constitutional Court, through the Judicial Yuan Interpretation no. 690, explicitly acknowledges that some risk-based decision is non-judiciable and that judiciary intervention should be minimal. As such, the Court effectively deferred the decision-making to the executive, which is consistent with the broader international trend where judges are reluctant to rule against experts during public health emergences. ${ }^{28}$ Nonetheless, the Constitutional Court also underscores four principles that should guide the CDC Act amendments. In the Constitutional Court's view, a compulsory quarantine measure should be: (1) Of limited duration; (2) provided by due process; (3) subjected to appeal; and that (4) affected individuals are entitled to adequate compensation. Accordingly, when the Legislative Yuan (parliament) promulgated the Special Act for Prevention, Relief, and Revitalization Measures for Severe Pneumonia with Novel Pathogens (Special Covid-19 Act), enacted on February 25, 2020, Article 9 provided a legal basis for compensation for those who are subjected to a compulsory quarantine order.

The concern over the potential misuse and abuse of government power is expressed eloquently by the dissenting Justice Tzong-Li Hsu, who recognizes that political leaders and experts are not immune from abusing their authority. As such, the judiciary should function as to safeguarding potential misuse and abuse of government's power:

Whether or not they are specialists, leaders can abuse their authority. This was certainly a key point that we considered. There are many historical examples of authorities using mental illness as a justification for purging political dissidents.

\footnotetext{
${ }^{26} I d$. However the CDC Act was not amended accordingly after the issuance of the Interpretation.

${ }^{27}$ The Immigration Detention of Foreign Nationals Pending Deportation Case, Interpretation No. 708, CONST. CT. INTERP., JUdiCIAL YUAN, R.O.C., para. 3-4 (Feb. 6, 2013), https://cons.judicial.gov.tw/jcc/en-us/jep03/show?expno=708 (Taiwan).

${ }^{28}$ Thérèse Murphy \& Noel Whitty, Is Human Rights Prepared? Risk, Rights, and Public Health Emergencies, 17 MED. L. REV. 219 (2009).
} 
Aside from the infamous example of such abuses under the KGB in the former Soviet Union, today in the 21st century, in different corners of the world and in different cultures, there are still disgraceful examples of homosexuals or religious minorities who are labelled as mentally ill and dealt with accordingly. These cases all have something in common: experts and specialists participate in the determination of whether a person is mentally ill.

Perhaps the reader feels that fighting epidemics and mental illness are different, and that the analogy is not valid. But as there are cases of dissidents persecuted in the name of treating mental illness, this judge cannot help but be wary of compulsory isolation decisions during times of infectious disease.

Moreover, there are documented examples such as the case of Typhoid Mary in America in the previous century. Because she was suspected as the originator of typhoid, she spent the rest of her life in forced isolated custody, a total of 26 years. Her case was never heard in a court of law. Scholars believe that the discriminatory treatment that she received is not unrelated to her background as an Irish immigrant.

Even if we have confidence in the persistence of Taiwan's free and democratic rule of law, as well as the tolerance and attention to human rights found in Taiwanese people; even if we feel that what we worry about is no longer possible in our modern Taiwan, we still cannot take that risk. The principle of judicial retention (法官保留, meaning certain actions by the government require the approval of a judge) intends to prevent abuse of authority to the greatest extent possible, even if such cases constitute a fraction as small as one in a million. ${ }^{29}$

Importantly, the dissenting opinion points out that the Court should be able to conduct an expost review in order to scrutinize the risk-based evidence per legal norms. Such an approach would have preserved the rule-of law framework. Furthermore, according to Justice Hsu, such an approach would have enabled the judiciary to address potential bias from public health experts in making the compulsory quarantine determination, when such a determination relates to social determinants of health that underpin communicable diseases. ${ }^{30}$ In short, in Justice Hu's view, the judiciary would function as a safeguard to potential abuse of power by the executives. ${ }^{31}$

\footnotetext{
${ }^{29}$ For an English translation of the dissenting justice's opinion, please see Chang Tze-wu, The SARS Doctors: How Three Doctors Survived Taiwan's Worst Quarantine, REPORTER (Mar. 12, 2020), https://www.twreporter.org/a/sars-memories-lifeunder-quarantine-in-heping-hospital-english. As a consequence of the Judicial Yuan Interpretation No. 690, in which the Constitution Court recognized the principle, judicial retention-where an independent court can intervene in the decision by the executive-is not applicable in quarantine for public health reasons. This Interpretation also aligns Taiwan's legal practice with international human rights law. However, without the principle of judicial retention, it made it harder for Courts to address disproportionate burdens due to individual circumstances when individuals are subjected to compulsory quarantine.

${ }^{30}$ Sara J. Cromer, Chirag M. Lakhani, Deborah J. Wexler, Sherri-Ann M. Burnett-Bowie, Miriam Udler, \& Chirag J. Patel, Geospatial Analysis of Individual and Community-Level Socioeconomic Factors Impacting SARS-CoV-2 Prevalence and Outcomes, MEdRXIV (Sept. 30, 2020),https:/www.medrxiv.org/content/10.1101/2020.09.30.20201830v1. See also DirectorGeneral, World Health Organization, Social Determinants of Health, EB 148/24 (Jan. 6, 2021), https://apps.who.int/gb/ ebwha/pdf_files/EB148/B148_24-en.pdf.

${ }^{31}$ In theory, the Constitutional Interpretation Procedure Law provides that the Constitutional Court may instruct the relevant agencies to execute the interpretation and take necessary actions. Arguably, had the Court opted for judicial activism in public health and declared the compulsory quarantine unconstitutional, such an approach would have enabled the Court to include social determinants as part of the ex-post review in the risk assessment and instructed the agencies to adjust policies accordingly. Empirical studies have suggested socio-economic status correlates to risk of infection in COVID-19, where the exposure of risk factors differ considerably across population groups.
} 
However, as the Article demonstrates below, developing a human rights-based approach as part of "public health emergency legal preparedness" 32 remains a slow progress in Taiwan. Such inadequacy is detrimental to the protection of vulnerable populations: Frontline health workers, children, minorities, migrant workers, older persons, and persons with disabilities.

\section{The Rise of Technocracy in the COVID-19 Pandemic}

Arguably, Taiwan's strong technocratic response to COVID-19 is in keeping with the government's obligation to protect the right to life and the right to health, where states have a positive duty to protect and ensure the right to life, which includes taking measures to eliminate an epidemic. ${ }^{33}$ In that context, the Taiwanese government has taken extraordinary steps in preserving scarce medical resources which has fulfilled the obligation. Taiwan's relative success in its pandemic response has earned the self-governing island-nation of 23.5 million worldwide praises for its pandemic response during the first year of the pandemic. ${ }^{34}$ The markedly different governmental responses in the SARS outbreak and current pandemic response can be, in part, attributed to the public health reform that took place after the SARS outbreak.

The devastation of the 2003 SARS outbreak, where Taiwan suffered from the highest mortality rate worldwide, had shaken the national consciousness. This may explain the island's institutional preparedness and investment in preventive state capacity in the post-SARS period. A technocratic approach, where decisions are made by medical and public health experts, tends to focus on the collective right to health and life as opposed to individual right to privacy and liberty. While a technocratic approach was initially criticized by scholars, as the pandemic spread across countries, Taiwan's strong technocratic approach had maintained normality for the first sixteen months of the pandemic. Likewise, the allure of expertise had also successfully compelled the public to follow advice regarding non-pharmaceutical measures during the early phase of the pandemic. However, as the analysis shows, technocrats are not always well-positioned to address the distributional impacts of the pandemic. As the judiciary is reluctant to intervene in the executive's decisions, this reluctance has seen a mixed result in terms of human rights protections. On the one hand, the expansion of public power at times can enhance collective human rights protections. On the other hand, the government's overreach can undermine the exercise of individual human rights. Insofar as such tension is inherent during the pandemic as the government needs to weigh competing interests and make decisions in a timely manner, this suggests a need for a robust regulatory system and external oversight with broad-basis participation.

This Article now turns to the public health reform and the legal architecture of infectious disease control.

\section{The Communicable Disease Control Act}

Many scholars and public health practitioners often describe the 2003 SARS outbreak as a dress rehearsal for the COVID-19 pandemic, where Taiwan's proactive approach was widely praised and a source of national pride. Importantly, the 2003 SARS crisis catalyzed a wave of public health reform and the Judiciary Interpretation No. 690 which cemented a technocratic approach to

\footnotetext{
${ }^{32}$ Centers for Disease Control and Prevention (CDC), Legal Preparedness for Public Health Emergencies: A Model for Minimum Competencies for Mid-Tier Public Health Professionals, at 5 (Sept. 17, 2012), https://www.cdc.gov/phlp/docs/ legal-preparedness-competencies.PDF.

${ }^{33}$ Antonio Coco \& Talita de Souza Dias, Part I: Due Diligence and COVID-19: States' Duties to Prevent and Halt the Coronavirus Outbreak, EJIL:TALK! (Mar. 24, 2020), https://www.ejiltalk.org/part-i-due-diligence-and-covid-19-statesduties-to-prevent-and-halt-the-coronavirus-outbreak/. See also, U.N. Hum. Rights Comm., CCPR General Comment No. 6: Article (Right to Life) (Apr. 30, 1982), https://www.refworld.org/docid/45388400a.html.

${ }^{34}$ See, e.g., Jason Wang, Chun Y. Ng, \& Robert H. Brook, Response to COVID-19 in Taiwan: Big Data Analytics, New Technology, and Proactive Testing, 323(14) JAMA 1341 (2020).
} 
public health emergencies. Put differently, as the Constitutional Court recognized the necessity of mandatory quarantine as a legitimate public health measure, it also paved ways to judicial deference to executives during the COVID-19 pandemic.

The Communicable Disease Control Act (CDC Act), updated after the 2003 SARS crisis, provides a regulatory framework for managing the emergence and re-emergence of infectious diseases. The Act was amended with bipartisan support, which was unusual as support is typically divided along party lines. Significantly, the CDC Act provides a legal basis for a centralized platform and establishes a national health command center tasked with steering and coordinating inter-agency responses during public health emergencies. Article 8 provides the head of the Ministry of Health and Welfare the legal authority to declare the existence of an epidemic. Once the proclamation is made, the Minister of Health can also determine whether the condition would warrant the establishment of a Central Epidemic Command Center (CECC). Once established, the CECC is housed directly under the command of the Premier, which streamlines the decision-making process.

The CECC is also responsible for coordinating actions between different ministries. For instance, during the early stage of the pandemic schools had delayed opening for two weeks in order to maintain a healthy environment to protect students, teachers, and staff. Local governments were tasked with delivering essential medical supplies such as thermometers and hand-sanitizers to schools. The Ministry of Education was charged with determining the criteria in which classes would be suspended if community transmission of SARS-CoV-2 occurred. ${ }^{35}$ The CECC worked closely with the Ministry of Education over the logistics and guidelines. According to the Taiwan Centers for Disease Control (TCDC) website, the CECC also worked with ministries of interior, transportation, foreign affairs, economics, labor, education, and environment to ensure a concerted national response towards the pandemic. ${ }^{36}$ For instance, the Ministry of Interior is responsible for the use of social media to ensure the public has access to reliable and accurate information during the pandemic. ${ }^{37}$ To the extent possible, the inter-ministerial collaboration ensures that the right to information is fulfilled. Considerable efforts are directed at combating misinformation, fake news, and ensuring accurate information is accessible by the general public. In short, a technocratic approach is also a whole-government approach.

Prior to the 2003 SARS outbreak, the public health power was shared between the municipality and the central government. The sharing of power had added to chaos and confusion: During the 2003 SARS outbreak, local hospitals refused to admit patients suspected of contracting SARS, and an estimation of the available PPE in stock, island-wide, was logistically challenging as there was no clear command chain. ${ }^{38}$ Prompted by the SARS experience, where local and central authorities were out of step with each other, which resulted in a significantly delayed SARS response, Article 17 was amended accordingly. As such, the CDC Act consolidates power to the executive branch once a communicable disease is declared as an outbreak. A centralized command center streamlines decision making and ensures policies are implemented consistently across vertical and horizontal governance levels.

The CDC Act serves as the chief legal architecture of infectious disease control law, which was later supplemented by the Special Act for Prevention, Relief and Revitalization Measures for Severe Pneumonia with Novel Pathogens (also known as the COVID-19 Special Act),

\footnotetext{
${ }^{35}$ Prevention and Control of COVID-19 in Taiwan, TAIwAN CEnTERS FOR Disease CONTROL, (Apr. 29, 2021), https://www. cdc.gov.tw/En/Category/Page/0vq8rsAob_9HCi5GQ5jH1Q.

${ }^{36} I d$.

${ }^{37}$ U.N. Dep't of Glob. Commc'ns, Human Rights Council Discusses Human Rights Implications of the COVID-19 Crisis With Its Special Procedures Mandate Holders, ReLIEFWeB (Apr. 30, 2020), https://reliefweb.int/report/world/human-rights-councildiscusses-human-rights-implications-covid-19-crisis-its-special.

${ }^{38} \mathrm{Yu}$-Ju Chen, Po-Jung Chiang, Yu-Hsin Cheng, Chun-Wei Huang, Hui-Yun Kao, Chih-Kai Chang, Hsun-Miao Huang, Pei-Yin Liu, Jen-Hsin Wang, Yi-Chien Chih, Shu-Mei Chou, Chin-Hui Yang, \& Chang-Hsun Chen, Stockpile Model of Personal Protective Equipment in Taiwan, 15(2) HeAlth SEC. 170 (2017).
} 
promulgated on February 25, 2020. ${ }^{39}$ The Special Act was later amended to increase the relief budget from an initial $\$ 2$ billion to $\$ 7.1$ billion in April. ${ }^{40}$ Article 7 of the COVID-19 Special Act reaffirms Judicial Yuan Interpretation No. 690 the broad delegation of power to the executive branch during a pandemic, where the CECC may "for disease prevention and control requirements, implement necessary response actions or measures." 41

Article 9 provides the legal basis for the government to provide financial aid, subsidies, and tax cuts to assist industries, enterprises, and medical institutions from economic disruptions brought on by the COVID-19 pandemic. Article 18 further provides reporting requirements to the Legislative Yuan. Article 3 stipulates individuals who are subject to at-home quarantine or required to stay at designated quarantine facilities, and without any employment, may claim remuneration for their time while in quarantine. ${ }^{42}$ Initially all affected individuals, including foreigners, were entitled to compensation, but the remuneration claims were later narrowed to citizens and residents.

\section{Governing Through Technocracy}

Significantly, along with Judicial Yuan Interpretation No. 690, the CDC Act catalyzed a paradigm shift towards a technocratic governance of public health emergencies in Taiwan. This shift has included an increase in judicial deference to the executive: Individuals who challenged their fourteen-day mandatory quarantine in courts during the COVID-19 pandemic have not been successful. ${ }^{43}$ The CDC Act delegates broad power to the TCDC, and the COVID-19 Special Act, again, reaffirms that broad delegation. Taken together, the Constitutional Court and the legislative branch recognize that during times of national health emergencies, the Ministry of Health and Welfare (MOHW) should be afforded a wide degree of regulatory flexibility to implement measures necessary to contain the spread of communicable, infectious diseases. ${ }^{44}$ Since the 2003 SARS outbreak, awareness of the need to diversify the pandemic taskforce has seen membership expanded from medical doctors to include individuals with more diverse areas of expertise. For instance, the then-Vice President is an epidemiologist and the head of the MOHW, Dr. Chen Shih-chung, is a dentist by training. However, the current membership of the national pandemic taskforce remains predominately occupied by experts and academics from medical or public health backgrounds. The capacity to integrate a human rights perspective into the pandemic response remains challenging as no human rights experts are included in the taskforce. When the decision-making power is concentrated in the hands of the epistemic community, it may not accurately reflect the populations they seek to represent.

To be sure, the effectiveness of governmental response has functioned as a source of its legitimacy in Taiwan, and it is also true that a technocratic approach has-so far-proved effective in suppressing local transmission within the country. In the ensuing sections, this Article highlights the complexity of balancing competing human rights during the pandemic. The discussion herein reflects the broader debate in international law where scholars argue for a positive vision of human

\footnotetext{
${ }^{39}$ Dep’t of Info. Servs., COVID Relief and Stimulus for Industry, EXECUTIVE YUAN (Jan. 29, 2021), https://english.ey.gov.tw/ News3/9E5540D592A5FECD/09d1d995-fe7f-45b8-89ee-6a42d279a280 (Taiwan).

${ }^{40}$ Dep't of Info. Servs., COVID-19 Relief Measures for Individuals, ExECUTIVE YUAN (Jan. 29,2021), https://english.ey.gov. tw/News3/9E5540D592A5FECD/1d5e1254-7732-4f7e-9832-fb5e8620e12b (Taiwan).

${ }^{41}$ Special Act for Prevention, Relief and Revitalization Measures for Severe Pneumonia with Novel Pathogens, art. 7, promulgated by the Ministry of Health \& Welfare, rev'd May, 31, 2021, https://law.moj.gov.tw/ENG/LawClass/LawAll.aspx?pcode= L0050039 (Taiwan).

${ }^{42} I d$. at art. 3.

${ }^{43}$ Wen-Chen Chang \& Chun-Yuan Lin, Legislative/Judicial Deference versus NGOs/Citizens Activism: Taiwan's Successful Fight Against Covid-19, Verfassungsblog: on Matters Constitutional (Apr. 21, 2021), https://verfassungsblog.de/ legislative-judicial-deference-versus-ngos-citizens-activism-taiwans-successful-fight-against-covid-19/.

${ }^{44}$ Communicable Disease Control Act, promulgated by the Ministry of Health \& Welfare, rev'd Jun., 19 2019, https://law. moj.gov.tw/ENG/LawClass/LawAll.aspx?pcode=L0050001 (Taiwan).
} 
rights instead of a "litany of prohibition" as human rights law is conventionally conceived. ${ }^{45}$ As this Article demonstrates, a technocratic approach tends to prioritize the collective right to life and health over other human rights during the pandemic in Taiwan.

\section{Human Rights During the Pandemic}

International human rights law is part of Taiwan's legal order, as human rights treaties play a key role in shaping Taiwan's judicial and democratic landscape. Taiwan was a signatory to the International Covenant on Civil and Political Rights (ICCPR) and the International Covenant on Economic, Social and Cultural Rights (ICESCR) in 1967. But the expulsion from the United Nations in 1971 where China acceded Taiwan's seat, bars Taiwan from depositing the ratification instrument with the UN Secretary General. ${ }^{46}$ Nonetheless, efforts to align domestic laws with international human rights obligations came about through the Enforcement Act, which passed and came into effect in 2009. The Enforcement Act requires the government to implement the rights and obligations stipulated in these two Conventions and issue compliance reports, which are subjected to independent, international review. The Enforcement Act also requires the government to amend and revise relevant laws and regulations in accordance with the Conventions. In addition to these two Conventions, efforts also extend to the incorporation of the Convention on the Elimination of All Forms of Discrimination Against Women (CEDAW), the Convention of the Rights of Child, and the Convention on the Rights of Persons with Disabilities (CPRD) into domestic law.

\section{The Right to Life}

While Taiwan is not formally a party to the ICCPR because of political reasons, the right to lifeduties to protect the right to life-is central to the government's response to COVID-19, as provided in Article 3 of the Universal Declaration of Human Rights and Article 6 of the ICCPR. Protection of the right to life might justify derogations to some other human rights. ${ }^{47}$ As the analysis shows, a technocratic approach and the right to life make natural bedfellows: The broad discretion afforded to the TCDC has seen efficient and timely decision-making and, often, with remarkable transparency. General Comment No. 36 (2018) provides that " $[\mathrm{t}]$ he duty to protect the right to life by law also includes an obligation for States parties to adopt any appropriate laws or other measures in order to protect life from all reasonably foreseeable threats[,]" such threats include life threatening communicable diseases, where State parties need to take appropriate measures to address these threats that may prevent "individuals from enjoying their right to life with dignity[.]" Importantly, General Comment No. 36 also recognizes the economic and social dimension of the right to life, which includes access to healthcare. ${ }^{48}$

\section{The Right to Health}

Compared to other countries, Taiwan is relatively new to the right to health discourse, largely because the Constitution does not explicitly provide for the right to health. Historically, the Constitutional Court relied upon other Constitutional provisions to deal with the substantive content of the right to health. Recently, the debate over whether and how to incorporate the right to

\footnotetext{
${ }^{45}$ Karima Bennoune, "Lest We Should Sleep": COVID-19 and Human Rights, 114(4) AM. J. INT'L L. 666 (2020).

${ }^{46}$ Wen-Chen Chang, Taiwan's Human Rights Implementation Acts: A Model for Successful Incorporation?, in TAIWAN AND International Human Rights: A Story of Transformation (Jerome A. Cohen, William P. Alford \& Chang-fa Lo eds., 2018).

${ }^{47}$ See, e.g., Audrey Lebret, COVID-19 Pandemic and Derogation to Human Rights, 7(1) J. L. \& BIOSCIENCES (Jan. 2020).

${ }^{48}$ U.N. Hum. Rights Comm., CCPR General Comment No. 36, Article 6 (Right to Life) (Sept. 3, 2019), https://www.refworld. org/docid/5e 5e75e $04 . h t m l$.
} 
health, as provided in the International Covenant on Economic, Social and Cultural Rights (ICESCR), came into the spotlight in Judicial Yuan Interpretation No. 767, issued in $2018 .{ }^{49}$ Divergent views on the right to health-as a separate constitutional right provided by Article 22 or together with the right to existence as provided by Article 15-puzzled the Court. However, one year later, in Judicial Yuan Interpretation No. 785, the Court recognized that the right to health is within the scope of Article $22 .{ }^{50}$ As the right to health is not an enumerated right in the Constitution and is incorporated through Article 22, the content and contour of the right to health remain unclear; how to ensure that the right to health is interpreted in line with contemporary practices continues to occupy the mind of the Justices. Elsewhere, the former Justice Chang-fa Lo has argued that the interpretation of Constitutional provisions should be "read" as a living document in light of evolving contemporary practices. ${ }^{51}$ Such an interpretive approach would enable the Constitutional Court to take into consideration international human rights treaties and practices when interpreting the content of fundamental rights.

\section{ICESCR Article 12}

Article 12 of the ICESCR recognizes "the right of everyone to the enjoyment of the highest attainable standard of physical and mental health[.]" Under the ICESCR, governments discharge their responsibility by "prevent[ing], treat[ing], and control[ing] epidemics and other diseases and ... assur[ing] medical services for all in the event of sickness." 52 Specifically, Article 12(c) and (d) is directly applicable in the context of the pandemic, where Article 12(c) provides that State obligations in respecting, protecting, and fulfilling the right to health is through the prevention and control of the pandemic and Article 12(d) requires States to ensure that adequate medical and healthcare services are available to patients during the pandemic. In many ways, the right to health provides a framework to prescribe appropriate care and policy during the pandemic. The UN Committee on Economic, Social, and Cultural Rights (CESCR) released a statement on April 6, 2020 which urges governments to prioritize universal healthcare and "adopt appropriate regulatory measures to ensure that health-care resources ... are mobilized and shared among the whole population to ensure a comprehensive, coordinated health-care response to the crisis." 53 Importantly, the CESCR also urges that "responses to the pandemic should be based on the best available scientific evidence to protect public health." 54 Article 4 of the ICESCR contains the limitation clause and the CESCR also makes it clear that measures adopted in response to the pandemic should be "necessary to combat the public health crisis posed by COVID-19, and be reasonable and proportionate" and timebound where pandemic measures "should be lifted as soon as they are no longer necessary for protecting public health." ${ }^{\prime 5}$ Thus ensuring COVID measures are timebound is of central importance.

\footnotetext{
${ }^{49}$ Patients Who Have Common and Foreseeable Adverse Drug Reactions Are Not Eligible for Drug Injury Relief, Interpretation No. 767, CONST. CT. INTERP., JUDICIAL YUAN, R.O.C. (Jul. 27, 2018), https://cons.judicial.gov.tw/jcc/en-us/ jep03/show? expno=767 (Taiwan).

${ }^{50}$ Case Concerning the Protection of Civil Servants' Litigation Rights and the Way of Off-Duty and Overwork Compensation for Field Firefighters, Interpretation No. 785, CONST. CT. INTERP., JudiCial YuAN, R.O.C. (Nov. 29, 2019), https://cons.judicial. gov.tw/jcc/zh-tw/jep03/show? expno=785 (Taiwan).

${ }^{51}$ Lo, supra note 13 .

${ }^{52}$ U.N. Hum. Rights Comm, supra note 48.

${ }^{53}$ U.N. Comm. on Econ., Soc. and Cultural Rights, Statement on the Coronavirus Disease (COVID-19) Pandemic and Economic, Social and Cultural Rights, para. 13 (Apr. 6, 2020), https://www.google.com/url? sa=t\&rct=j\&q=\&esrc=s\& source=web\&cd=\&ved=2ahUKEwiC_u3ox_bxAhXTHc0KHcdMB1oQFjABegQIAxAD\&url=https\%3A\%2F\%2Fwww. ohchr.org\%2FDocuments\%2FHRBodies\%2FCESCR\%2FSTM_COVID19.docx\&usg=AOvVaw2kfjkR54uRdzEBqJ4F8iM_.

${ }^{54} I d$. at para. 10

${ }^{55} I d$. at para. 11
} 


\section{Lessons from the 2003 SARS Pandemic}

The 2003 SARS pandemic also exposed the inadequacy of hospital preparedness, as the collapse of hospital operations nearly paralyzed Taiwan's national response. ${ }^{56}$ Out of fear of hospital infections, some hospitals refused to treat patients with SARS-like symptoms, while the public's loss of confidence in hospitals saw patients avoiding seeking medical attention despite having symptoms. ${ }^{57}$ Public anxiety was also evident in the marketplace, where demands for face masks grew considerably. As supplies of masks were dependent on purchasing power instead of needs, it meant that healthcare workers and individuals with medical needs could not secure sufficient face masks. Some hospitals were hit hard by the increased costs for personal protective equipment (PPE). Shortages in facemasks and other personal protective equipment had seen healthcare providers using recycled PPE. ${ }^{58}$ The lessons from SARS had seen the government taking responsive actions when SARS-CoV-2 was first identified in China.

\section{Access to Healthcare During the COVID-19 Pandemic}

While the recognition of the right to health as a Constitutional right is a recent endeavor, since 1995, Taiwan has institutionalized a national health insurance scheme that provides equal access to all citizens, residents, and documented migrant workers. By 2004, the population coverage reached $99 \%{ }^{59}$. Insofar as the provision of universal health coverage is a practical expression of the right to health, as acknowledged by the $\mathrm{WHO},{ }^{60}$ the government has taken extraordinary measures in protecting the collective right to health in-so far-two instances during the pandemic, which is illustrative of a technocratic approach with a strong utilitarian overtone that this Article describes.

One of the early measures introduced by the government to ensure access to healthcare included the integration of national health records with immigration data from high-risk countries, generating real-time alerts and assisting with clinical identification of potential cases. ${ }^{61}$ Past experiences with Ebola, Zika, MERS, and SARS suggest infectious diseases are often geographically linked. Thus, integrating travel history as part of preliminary clinical assessment can lead to early diagnosis and detection through laboratory confirmation. ${ }^{62}$ Additionally, as the government has a positive duty to take appropriate steps to protect life where there is a known risk, real-time alerts about a patient's international travel history during a clinical visit enable the frontline health workers to take appropriate actions, including wearing protective gear and following infection prevention and control protocol during clinical consultations. Furthermore, at the time when the transmission route of SARS-CoV-2 remained unknown, asymptomatic carriers put healthcare workers at risk-relying on a patient's voluntary disclosure of their travel history is desirable but insufficient to protect frontline workers.

When the measure was first announced, it was heavily criticized as an infringement to a patient's right to privacy. However, given that any individual who is in contact with a confirmed case of the virus is required to undergo 14-days of home quarantine, whereas an individual with proper protective gear can forego the quarantine, it is arguable that real-time alerts would not only

\footnotetext{
${ }^{56}$ Hui-Yun Kao, Hai-Yun Ko, Peng Guo, Chang-Hsun Chen, \& Su-Mei Chou, Taiwan's Experience in Hospital Preparedness and Response for Emerging Infectious Diseases, 15(2) Health SeC. 175 (2017).

${ }^{57} I d$.

${ }^{58}$ Wei-Kung Chen, Hong-Dar Isaac Wu, Cheng-Chieh Lin, \& Yi-Chang Cheng, Emergency Department Response to SARS, Taiwan, 11(7) EMERGING INFECTIOUS DisEASES 1067 (2005).

${ }^{59}$ Tai-Yin Wu, Azeem Majeed, \& Ken N. Kuo, An Overview of the Healthcare System in Taiwan, 3(2) LONDON J. PrIMARY CARE 115 (2010).

${ }^{60}$ World Health Org. (WHO), Anchoring Universal Health Coverage in the Right to Health: What Difference Would It Make? (2015), https://www.who.int/gender-equity-rights/knowledge/anchoring-uhc.pdf.

${ }^{61}$ See Cromer et al., supra note 30.

${ }^{62}$ Trish Perl \& Connie Savor Price, Managing Emerging Infectious Diseases: Should Travel be the Fifth Vital Sign, ANNALS OF INTERNAL MEDICINE (Apr. 21, 2020), https://www.acpjournals.org/doi/10.7326/M20-0643.
} 
protect health workers, but also ensure conservation of critical healthcare resources. Furthermore, the UN Committee on Economic, Social, and Culture Rights has elaborated the right to health duties in relation to infectious disease control, which require states to use "technologies, epidemiological surveillance and data collection, immunization programs and other strategies of infectious disease control"63 which arguably extends to the integration of immigration data and national health records-provided that such a linkage is limited in duration and only used for clinical and public health purposes.

A more controversial measure to ensure that health goods, services, and facilities remain available during the pandemic concerns the travel restriction placed on frontline healthcare workers from February 23 to June 30, 2020. ${ }^{64}$ The measure entailed outbound travel restrictions for frontline healthcare workers who were planning to travel abroad, requiring them to seek approval from their respective line managers and outright prohibiting travel to certain countries. ${ }^{65}$ While the government provides financial compensation to those individuals affected by the measure, the temporary suspension of freedom of movement of frontline health workers caused a public outcry. Again, the government's rationale for implementing the measure remains the provision of health goods, services, and facilities during the pandemic. The government argues that the restriction was necessary to ensure Taiwan has sufficient healthcare workers to contain COVID-19. ${ }^{66}$ While arguably the government is afforded such a broad discretion in enacting the measure-Article 7 of the Special Act grants such an expansive power which is only subject to necessity-medical unions released a statement pointing out that they should have been involved in the decision-making process. ${ }^{67}$ While the measure has not been challenged in court, it is doubtful that the travel measure would achieve its goal as the border remained open to other individuals at the time.

These two measures demonstrate the extraordinary length that the government is willing to take to ensure health goods, services, and facilities remain functional during the pandemic. Such a position is perhaps understandable from a historical perspective: During the 2003 SARS crisis the mortality of frontline health workers was at an astoundingly high rate of $14 \% .{ }^{68}$ Accordingly, the hard lesson from the 2003 SARS crisis had shaped the subsequent technocratic approach in Taiwan with a strong utilitarian tone.

\section{Travel Restriction During the Pandemic and ICCPR Article 12}

The travel restriction on healthcare workers has not been challenged in Taiwanese courts. However, as countries have implemented international travel restrictions with varying levels of restriction on the freedom of movement during the pandemic, it is instructive to turn to Australia's travel measure. Specifically, Australia's suspension of citizens and residents from leaving the country, which was challenged in Australia's Federal Court. The case was unsuccessful as the justices agreed with the government unanimously. ${ }^{69}$ The Federal Court acknowledged that during a pandemic, the government must be afforded a broad power where "the Health

\footnotetext{
${ }^{63}$ U.N. Comm. on Econ., Soc. and Cultural Rights, supra note 53, at para. 16.

${ }^{64}$ Taiwan Bans Its Healthcare Professionals from Traveling Abroad, Focus TAIWAN: CNA English News (Feb. 23, 2020), https://focustaiwan.tw/society/202002230009.

${ }^{65}$ Dep't of Med. Affairs, During The Epidemic Prevention Period, Hospital Medical Staff And Social Workers Going Abroad And Related Compensation Regulations Will Apply From February 23, Ministry of Health \& Welfare (Feb. 27, 2020), https://www.mohw.gov.tw/cp-16-51720-1.html (measure concerning compensation for essential health workers affected by the restrictions).

${ }^{66}$ Lee I-chia, Virus Outbreak: CECC Clarifies Medical Staff Travel Ban, TAIPEI Times (Feb. 25, 2020), http://www. taipeitimes.com/News/taiwan/archives/2020/02/25/2003731579.

${ }^{67} I d$.

${ }^{68}$ Kow-Tong Chen, Shiing-Jer Twu, Hsiao-Ling Chang, Yi-Chun Wu, Chu-Tzu Chen, Ting-Hsiang Lin, Sonja J. Olsen, Scott F. Dowell, Ih-Jen Su \& Taiwan SARS Response Team, SARS in Taiwan: An Overview and Lessons Learned, 9(2) INT'L J. INFECTIOUS DiSEASES 77 (2005).

${ }^{69}$ Liberty Works Inc. v Commonwealth [2021] FCR 90 (Austl.).
} 
Minister is entitled to impose any requirement he is satisfied is necessary, amongst other things, to prevent or control the entry of COVID-19 into Australian territory or the spread of the disease in Australia or elsewhere." 70 This power extends to the outbound travel restriction where, according to the Federal Court, the restriction might be the most effective way of protecting Australia from the pandemic. ${ }^{71}$ Furthermore, Australia is also a signatory to the ICCPR. The Federal Court pointed out that the freedom of movement is not an absolute right under international human rights law and may be derogated from during a public health emergency. ${ }^{72}$

Importantly, in determining whether the measure is necessary under the Biosecurity Act-the law that governs the power of government during a public health emergency-the health minister must demonstrate that the measure is effective, appropriate, and adapted to achieve the purported purpose, no more restrictive or intrusive than the circumstances require, applied in a manner no more restrictive or intrusive than the circumstance require, and timebound. ${ }^{73}$ These restrictions on public power also reflect human rights principles more broadly. These five conditions provide a safeguard to the potential overreach of government power. In contrast, under Article 7 of the Special Act, by which the Taiwanese government is also afforded a similar discretion during a public health emergency, a close examination of the provision reveals no further limitations to that power. Integrating human rights principles into the Special Act would also help safeguard from overreach by the government.

\section{Other Human Rights \\ 1. Labor Rights of Healthcare Professionals}

Attention on inadequate legal protections afforded to healthcare workers came to light with the devastation of the SARS outbreak during which the self-governing island had the highest mortality rate of healthcare workers in the world. ${ }^{74}$ During the COVID-19 pandemic, the same group of individuals still face disproportionate risk and stigmatization because of their profession and the nature of their work.

Worldwide, health care providers face stigmatization partly because of insufficient information and widespread fear about the virus. ${ }^{75}$ Although in Taiwan, the medical profession generally occupies a higher social status, those individuals working in the designated facilities during the pandemic often face intolerance, exclusion, and social stigma from their neighbors and strangers. Their children can also face bullying from their peers. ${ }^{76}$ Without adequate housing support from the government, ${ }^{77}$ those working in the COVID response teams often face difficult choices when they return home. Fear of infecting family and friends saw some health care workers opt to stay at rental places. The European Commissioner for Human Rights has therefore recommended providing childcare for essential health services workers. ${ }^{78}$ Such a recommendation could also be adopted in Taiwan. While the government has provided remuneration and adequate personal

\footnotetext{
${ }^{70} \mathrm{Id}$. at para 55 .

${ }^{71} I d$. at para. 67.

${ }^{72} I d$. at para. 70 .

${ }^{73} I d$.
}

${ }^{74}$ L. Clifford McDonald, Andrew E. Simor, Ih-Jen Su, Susan Maloney, Marianna Ofner, Kow-Tong Chen, James F. Lando, Allison McGeer, Min-Ling Lee \& Daniel B. Jernigan, SARS in Healthcare Facilities, Toronto and Taiwan, 10(5) EMERGING INFECTIOUS DisEASES 777 (2004).

${ }^{75}$ Sanjeet Bagcchi, Stigma During the COVID-19 Pandemic, 20(7) LANCET INFECTIOUs DisEASES 782 (2020).

${ }^{76}$ Editorial: Virus Discrimination Continues, TAIPEI TIMES (Apr. 01, 2020), https://www.taipeitimes.com/News/editorials/ archives/2020/04/01/2003733758.

${ }^{77}$ See Jennifer K. Wagner, Health, Housing, and 'Direct Threats' During a Pandemic, 7 J.L. \& BioscienCES (May 2020) (noting that in the U.S., healthcare providers are also grappling with rental issues).

${ }^{78}$ U.N. Comm'r for Hum. Rights, Human Rights Comment, Learning from the Pandemic to Better Fulfil the Right to Health (Apr. 23, 2020), https://www.coe.int/en/web/commissioner/-/learning-from-the-pandemic-to-better-fulfil-the-right-tohealth?inheritRedirect $=$ true\&redirect $=\% 2 \mathrm{Fen} \% 2 \mathrm{Fweb} \% 2 \mathrm{Fcommissioner}$. 
protection equipment to frontline workers, ${ }^{79}$ improvement in workplace safety, social, mental, and psychological support is a vital ${ }^{80}$ but often neglected topic. ${ }^{81}$

Generally, healthcare providers in Taiwan are overworked and underpaid when compared to their counterparts in other parts of the world. ${ }^{82}$ While Taiwan established a National Health Insurance (NHI) scheme in 1995, the affordability and accessibility of health care services means that the average number of physician visits per year is nearly double than that of other developed economies. ${ }^{83}$ Despite that, the NHI has ranked as one of the world's most efficient systems. It is compulsory for all local citizens, although the affordability of health care services can lead to wasted resources. Brain drain of health care providers remains an overlooked social problem: Asymmetry of NHI fees relative to providers' training has seen chronic shortage of nurses and doctors, ${ }^{84}$ where nurse and doctors ratios in Taiwan are 5.7 nurses and 1.7 doctors per 1,000 individuals, compared to the OECD median of 8.6 nurses and 3.3 doctors ${ }^{85}$ Hospitals tend to favor services with high profit margin such as CT scans and MRIs, and there are little incentives for doctors to spend time providing consultations to patients as fees for such services are minimal. Excessive prescribing of medicine is a prevalent challenge as the system is structured in such a way to encourage over-prescription of medicine. While the NHI has played a pivotal role in the COVID-19 pandemic, questions over the sustainability of the NHI in providing fair and quality access for all still looms. If a human-rights focus to public health is desirable, then the sustainability of the current healthcare system would also need to be critically examined.

Like elsewhere in the world, austerity measures continue to burden the health care system, where diminishing public spending on health care and infrastructure is affecting the quality of care. In Taiwan, chiefly because of the affordability and accessibility of health care services, a tendency exists where individuals would seek treatments even for minor ailments which unnecessarily drains health care resources. This creates a moral hazard, making the publicly funded health system unsustainable in the long term. ${ }^{86}$ Paradoxically, insofar as the affordability of the NHI correlates to the high utilization rate of its services, the right to health cannot be realized without addressing resource allocation and distributional effects of high utilization of medically unnecessary treatments. An individualist framing of the right to health can overlook the overall impact on access at the population level.

\section{Labor Rights of Hospital Cleaning Service Workers}

In fact, Heping Hospital's super spreader event during the 2003 SARS crisis was the result of hospital out-sourcing cleaning services as part of the government's austerity measures. Laundry workers unwillingly contributed to the spread of the virus as clothing from potential SARS patients were passed to them. Financial pressure to decrease operational costs of the hospital meant no

\footnotetext{
${ }^{79}$ CORONAVIRUS/Taiwan to Boost Pay for Frontline Healthcare Workers Amid COVID-19, FocUs TAIWAN: CAN ENGLISH NEws (May 9, 2020), https://focustaiwan.tw/society/202005090013.

${ }^{80}$ Shu-Ching Chen, Yeur-Hur Lai \& Shiow-Luan Tsay, Nursing Perspectives on the Impacts of COVID-19, 28(3) J. NuRSING RscH. e85 (2020).

${ }^{81}$ For a discussion on the reciprocal responsibility of the government and institutions to minimize risks to health care providers, please see Francis Bakewell, Merril A. Pauls, \& David Migneault, Ethical Considerations of the Duty to Care and Physician Safety in the COVID-19 Pandemic CJEM (Apr. 2020).

${ }^{82}$ COVID-19: Taiwanese Nurse in Australia and the Cultural Differences, BBC News (Aug. 18, 2020), https://www.bbc.com/ zhongwen/trad/world-53810102.amp.

${ }^{83}$ Dylan Scott, Taiwan's Single-Payer Success Story-And Its Lessons for America, VOX (Jan. 13, 2020), https://www.vox. com/health-care/2020/1/13/21028702/medicare-for-all-taiwan-health-insurance.

${ }^{84}$ Tsung-Mei Cheng, Taiwan's Health Care System: The Next 20 Years, BrookIngs (May. 14, 2015), https://www.brookings. edu/opinions/taiwans-health-care-system-the-next-20-years/.

${ }^{85} \mathrm{Id}$.

${ }^{86} I d$.
} 
special training was provided to these external workers. ${ }^{87}$ However, the incident did not lead to structural change of the NHI's financial organization.

Without structural changes to the NHI, hospital cleaners are also more vulnerable to infection largely due to their status as unskilled laborers during the COVID-19 pandemic. While the government has ensured all healthcare workers-including cleaners-have adequate PPE, it remains unclear if this includes training in the safe use of disinfectants and instruction in the proper use of PPE. Article 12(2)(b) of the ICESCR requires states to ensure "the improvement of all aspects of environmental and industrial hygiene" and this positive obligation includes minimizing the risk of transmission. ${ }^{88}$

\section{Distribution of Scarce Medical Resources: National Mask Rationing Scheme}

The obligation to fulfil the right to health includes the provision of health goods and services. The provisions of health goods include face masks, as they can prevent the transmission of disease between people. During the early phase of the pandemic, the government's preparedness response included establishing a rationing scheme for face masks. This scheme ensured citizens could purchase face masks for an affordable price at local NHI-contracted pharmacies by using their national health insurance card. ${ }^{89}$ The scheme is remarkable, as it decouples the economic value associated with face masks, which is normally determined by a market mechanism. The government sought to avoid making the same mistake made during the 2003 SARS outbreak when prices for face masks surged unreasonably. The rationing scheme also created a sense of national unity and ensured fair access by all: More facemasks were allocated to children under the age of 12 , with special mask sizes manufactured for toddlers. When the scheme was first introduced, the civil society developed a crowd-sourced database to show the availability of masks in local pharmacies. ${ }^{90}$ Remarkably, by making face masks universally available, it also helped to significantly reduce local transmission. While the masks were first only available to citizens, the government quickly revised the scheme to make it accessible to migrant workers and foreigners. As the face masks were rationed, it also ensured that less privileged populations had access to face masks because the acquisition of face masks did not depend on individual purchasing power. However, when the scheme was first introduced, it was met with opposition from the opposition party and criticisms from some scholars for unwanted intrusion on property rights.

\section{Vulnerable Populations}

Taiwan's COVID-19 response, while effective, has largely been public health oriented. Focusing on maintaining a healthy environment and reducing the transmission chain within the community has been, and rightly, a top priority for the government. However, integrating a human rights perspective into the pandemic response would also ensure policies are implemented and guided by principles of non-discrimination, participation, empowerment, and accountability. For instance, delays in school openings had seen women disproportionately affected by the policy. Despite the success of the COVID-19 response in Taiwan, there remains a need to protect against genderbased violence and offer flexible working conditions for individuals who often also assume caregiver roles in families. ${ }^{91}$ For instance, from March to June in 2020, the tourism sector had been considerably affected by the spread of the coronavirus. Job opportunities dissipated, adding to the

\footnotetext{
${ }^{87}$ Chang, supra note 29.

${ }^{88}$ U.N. Comm. on Econ., Soc. and Cultural Rights, General Comment No. 14: The Right to the Highest Attainable Standard of Health (Art. 12 of the Covenant), para. 15 (Aug. 11, 2000), https://www.refworld.org/docid/4538838d0.html.

${ }^{89}$ TAinan CENTERS FOR Disease CONTROL, supra note 35.

${ }^{90}$ Jaron Lanier \& E. Glen Weyl, How Civic Technology Can Help Stop A Pandemic: Taiwan's Initial Success is a Model for the Rest of the World, ForEIGN AfFAIRS (Mar. 20, 2020), https://www.foreignaffairs.com/articles/asia/2020-03-20/how-civictechnology-can-help-stop-pandemic.

${ }^{91}$ Sharifah Sekalala, Lisa Forman, Roojin Habibi, \& Benjamin Mason Meier, Health and Human Rights are Inextricably Linked in the COVID-19 Response, 5(9) BMJ GLOB. HeAlth (Sept. 2020).
} 
financial stress of those who were working in the service sector. While the tourism sector has since rebounded and domestic tourism has recovered, insofar as more women than men are engaged in the informal economy sector in the tourism and hospitality industry, the gender-based impacts were overlooked by the government's economic relief response.

While the government acted swiftly in providing economic stimulus packages to a wide variety of sectors, it missed the opportunity to shape society in a more equitable way because these government assistances were provided without conditions attached..$^{92}$ For instance, the growing digital gig economy of food delivery service — such as Food Panda and UberEATS — has also received a no-strings-attached bailout from the government. But as the economic relief is without conditions attached, it is a missed opportunity to address the fundamental power imbalance between couriers and their companies. The aggressive expansion of UberEATS, for instance, came at the expense of worker's social protection. In Taiwan, food couriers are outside of the protections of labor laws, which means that employers are not required to pay for the couriers' national health insurance. ${ }^{93}$ The increased use of food delivery services during the pandemic may also put these couriers more at risk. Despite that, these risks are internalized by the individual courier. ${ }^{94}$ The government could have structured the economic relief to improve working conditions of couriers by mandating decent wage and labor rights protections.

Insofar as there is a need to embrace diverse viewpoints, especially in COVID-19 recovery responses, insights from human rights practices can steer towards an inclusive society by embracing a diversity of lived experiences which are, arguably, currently lacking in a technocratic approach. A technocratic approach is likely to be effective in containing the pandemic, but unlikely to be transformative in the long term as public health measures and their economic, social, and political consequences are less likely to be apparent to technocrats.

\section{E. Conclusion}

Through a historical-legal look at the emergence of technocracy as a governance model during the pandemic in Taiwan, this Article uncovers a more nuanced picture of the role of government and the judiciary during the pandemic. On one hand, as a technocracy is afforded a broad authority to protect public health, a technocracy is also better at protecting a positive version of human rights - specifically, the collective right to life and health. On the other hand, the analysis also shows that the expansion of the power of government also risks encroaching other human rights-privacy, work, and liberty, for instance. In Taiwan, courts tend to defer to the executive during a public health crisis. This has seen a strong-handed pandemic response from the government. As the COVID-19 pandemic is a public health crisis that brings challenges to economic, social-cultural rights, and civil and political rights, an effective pandemic response must also embrace and address the breadth and complexity of the rights implicated in pandemic measures.

\footnotetext{
${ }^{92}$ See, e.g., Mariana Mazzucato, Capitalism After the Pandemic: Getting the Recovery Right, ForeIGN AfFAIRS (Nov. 2020), https://www.foreignaffairs.com/articles/united-states/2020-10-02/capitalism-after-covid-19-pandemic.

${ }^{93}$ Dino Wei, Gig Economy Must Pay Its Share, TAIPEI TIMES (Oct. 24, 2019), https://www.taipeitimes.com/News/editorials/ archives/2019/10/24/2003724524.

${ }^{94}$ Dennis Xie, Virus Outbreak: Food Delivery Soars 50\% Amid Fear of Eating Out, TAIPEI TIMEs (Mar. 27, 2020), https:// www.taipeitimes.com/News/taiwan/archives/2020/03/27/2003733475. Urban Eats has introduced contactless delivery but it is uncertain if protective gears are protected.
}

Cite this article: Lee T-L (2021). The Rise of Technocracy and the COVID-19 Pandemic in Taiwan: Courts, Human Rights, and the Protection of Vulnerable Populations. German Law Journal 22, 1115-1132. https://doi.org/10.1017/glj.2021.49 